\title{
Bacteremic skin and soft tissue infection caused by Prevotella loescheii
}

\author{
Mansoor Mehmood ${ }^{1}$, Nabil A Jaffar ${ }^{1}$, Muhammad Nazim $^{2}$ and Faisal A Khasawneh ${ }^{1 *}$
}

\begin{abstract}
Background: Anaerobes are a major component of gut flora. They play an important role in the pathogenesis of infections resulting from breaches in mucus membranes. Because of the difficulties in cultivating and identifying it, their role continues to be undermined. The purpose of this paper is to report a case of Prevotella loescheii bacteremic skin and soft tissue infection and review the literature.
\end{abstract}

Case presentation: A 42-year-old Caucasian man was admitted for an elective bariatric surgery. A lengthy intensive care unit stay and buttocks decubitus ulcers complicated his post-operative course. After being transferred to a long-term care facility, the decubitus ulcer became secondarily infected with multiple bacteria including P. loescheii; an anaerobe that grew in blood and wound cultures. The patient was treated successfully with aggressive surgical debridement, antibiotics and subsequent wound care.

Conclusion: P. loescheii colonizes the gut and plays an important role in periodontal infections. In rare occasions and under suitable circumstances, it can infect skin and soft tissues as well as joints. Given the difficulties in isolating anaerobes in the microbiology lab, considering this bacterium alongside other anaerobes in infections of devitalized tissue is indicated even if cultures were reported negative.

Keywords: Anaerobe, Bacteremia, Prevotella loescheii

\section{Background}

Decubitus ulcers are a common complication of chronic critical illness [1]. The problem becomes more devastating when those wounds become secondarily infected. This infection is usually poly-microbial [2]. Culprit pathogens include streptococci, staphylococci and enterobacteriaeae [3]. Anaerobes, spreading from adjacent mucosal surfaces, can play a role in this infection especially when there is ischemia and significant tissue necrosis [2]. Bacteroides, peptostreptococcus and clostridium species are the most common anaerobic isolates [4]. Anaerobic bacteremia complicating this infection is rarely encountered.

We report a case of infected decubitus ulcer caused by multiple microorganisms including Prevotella loescheii. This anaerobe was also isolated in blood cultures, which has not been previously reported.

\footnotetext{
* Correspondence: faisal.khasawneh@ttuhsc.edu

${ }^{1}$ Section of Infectious Diseases, Department of internal medicine, Texas Tech University Health Sciences Center, 1400 S. Coulter Street, Amarillo, TX 79106, USA Full list of author information is available at the end of the article
}

\section{Case presentation}

A 42 year-old white male with a past medical history significant for morbid obesity (body mass index of 41) admitted for an elective bariatric surgery, Roux-en-y gastric bypass. His post-operative course was complicated by early ventilator-associated-pneumonia, septic shock, acute renal failure and right middle cerebral artery stroke. He had a lengthy intensive care unit (ICU) stay and required hemodialysis and tracheostomy. He was transferred to a long-term acute care hospital (LTACH) after 29 days in the acute care hospital ICU.

In the LTACH, the patient's condition gradually improved with return of his kidney function and successful liberation from mechanical ventilation. The patient, however, continued to remain bedridden due to extensive left sided weakness and severe deconditioning. During this hospitalization, he also developed buttocks decubitus ulcers that was managed conservatively. In the $9^{\text {th }}$ week of his illness he developed a new fever of $38.2^{\circ} \mathrm{C}$. He had no respiratory symptoms, his tracheostomy tube was already removed and his chest X-ray was negative. He had no gastrointestinal symptoms and his abdominal exam, 
including the surgical site, was unremarkable. He had a foley catheter but his urinalysis and urine culture were negative. He had a single peripheral intravenous catheter without any surrounding redness or tenderness. Two sets of blood cultures were obtained but were negative.

Despite several days of broad-spectrum antibiotic coverage with vancomycin and pipracillin/tazobactam he continued to have low-grade fevers. On examination, the left buttock decubitus ulcer had a black eschar with foul smell (Figure 1). Surgical consultation was placed; the patient underwent computed tomography scan of the pelvis (Figure 2) and bedside limited debridement with collection of a swab culture (BBL CultureSwab collection and transport system, Becton, Dickinson and company, Sparks, MD, USA) from the base of the wound after removing the eschar. Shortly afterwards, he had a fever of $40.3^{\circ} \mathrm{C}$ and he became confused and hypotensive. The patient was transferred back to the ICU of the acute care hospital with severe sepsis. His white blood cell count was $17.3 \times 10^{9} / \mathrm{L}$ with $20 \%$ bands and his creatinine increased to $1.8 \mathrm{mg} / \mathrm{dl}$. Two sets of blood culture (VersaTrek, TREK Diagnostic Systems, Cleveland, $\mathrm{OH}, \mathrm{USA}$ ) were collected and his antibiotics were broadened to linezolid and meropenem and he received aggressive intravenous fluid resuscitation. He was taken back to the operating room for several rounds of debridement that involved resection of significant amounts of skin and soft tissues of both buttocks with removal of the devitalized left sided gluteal muscles.

The anaerobic bottles in both blood culture sets grew Prevotella loescheii and the surgical sample grew extended-spectrum beta-lactamase (ESBL) producing Escherichia coli, ampicillin-susceptible Enterococcus faecalis and P.loescheii. Bacterial identification was performed

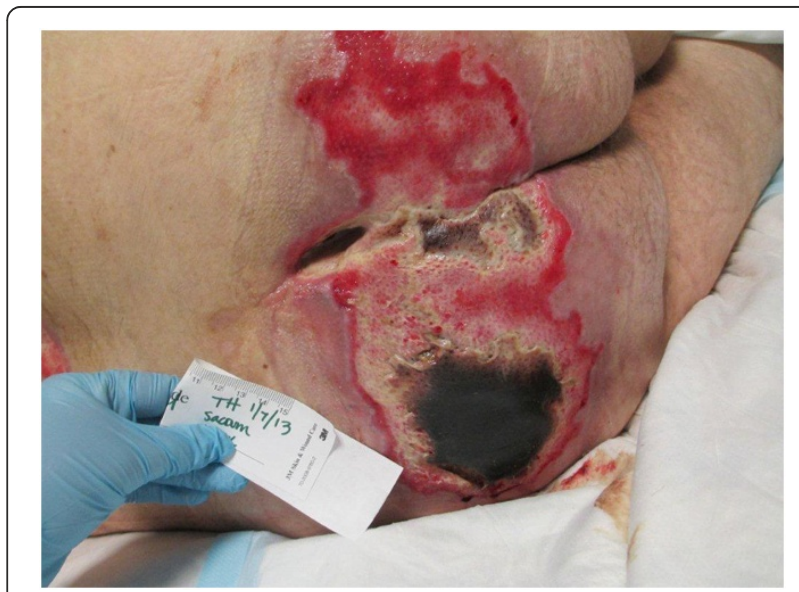

Figure 1 The patient's unstageable decubitus ulcers with a black eschar covering the left buttocks ulcer.

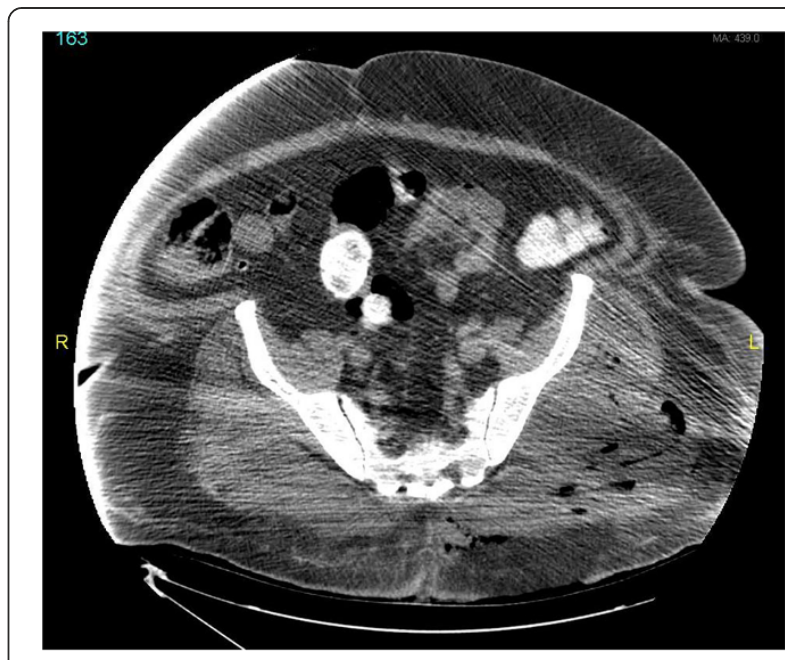

Figure 2 Computed tomography cross section of the pelvis showing a skin defect corresponding to the eschar that was removed with underlying fat stranding, inflamed muscles and gas pockets throughout tissue planes.

by Microscan WalkAway plus system (Siemens, Germany). No susceptibility testing was performed on $P$. loescheii and antibiotics with well-reported activity against anaerobes, carbapenems, were used. The patient's sepsis gradually improved. His antibiotics were subsequently de-escalated to ertapenem and he finished a total of 3 weeks of therapy after the last debridement session. His left buttock wound continued to heal slowly over the course of several months (Figure 3).

\section{Discussion}

We presented a case of bactermic, infected decubitus ulcer in a young, albeit, debilitated, chronically ill patient. The role of $P$. loescheii in this mixed-infection is indisputable given the fact that it grew in both wound

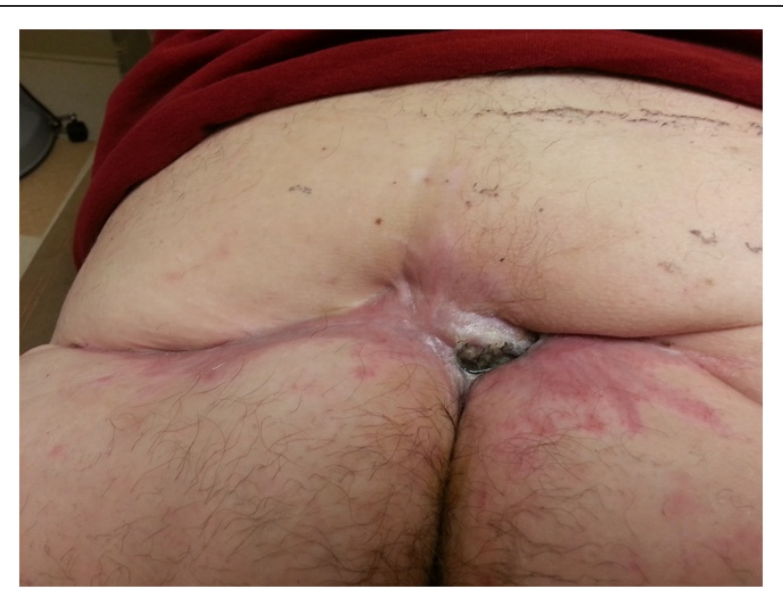

Figure 3 The patient's healing decubitus ulcer 9 months into treatment. 
Table 1 Important features of reported $P$. loescheii infection cases

\begin{tabular}{|c|c|c|c|c|c|c|}
\hline $\begin{array}{l}\text { Patient } \\
\text { characteristics }\end{array}$ & Co-morbidity & Infection & Cultured sample & Susceptibility testing & Treatment & Ref. no. \\
\hline 42 yо $M$ & $\begin{array}{l}\text { Decubitus ulcer in an } \\
\text { obese bedridden patient }\end{array}$ & $\begin{array}{l}\text { Bacteremic skin } \\
\text { and soft tissue } \\
\text { infection }\end{array}$ & $\begin{array}{l}\text { Blood and a } \\
\text { surgical sample }\end{array}$ & ND & $\begin{array}{l}\text { Ertapenam for } \\
3 \text { weeks }\end{array}$ & $\begin{array}{l}\text { Current } \\
\text { case }\end{array}$ \\
\hline 75 yo $M$ & $\begin{array}{l}\text { Dental extraction in a } \\
\text { patient with osteoarthritis }\end{array}$ & Septic arthritis & Synovial fluid & $\begin{array}{l}\text { Susceptible to PCN, BL/BL } \\
\text { inhibitor, metronidazole }\end{array}$ & $\begin{array}{l}\text { Amoxacillin-clavulante } \\
\text { for } 4 \text { weeks }\end{array}$ & {$[15]$} \\
\hline \multirow[t]{2}{*}{62 yo $M$} & Recurrent sinusitis & $\begin{array}{l}\text { Brain subdural } \\
\text { abscess }\end{array}$ & Pus & $\begin{array}{l}\text { Susceptible to PCN, BL/BL } \\
\text { inhibitor, clindamycin, } \\
\text { chloramphenicol. }\end{array}$ & $\begin{array}{l}\text { Chloramphenicol and } \\
\text { clindamycin for } \\
5 \text { weeks }\end{array}$ & [12] \\
\hline & & & & Resistant to metronidazole. & & \\
\hline 20 yo $\mathrm{M}$ & $\begin{array}{l}\text { Dental procedures in a } \\
\text { patient with R. hip } \\
\text { replacement }\end{array}$ & $\begin{array}{l}\text { R. hip prosthetic } \\
\text { joint infection }\end{array}$ & $\begin{array}{l}\text { Surgically } \\
\text { obtained bone } \\
\text { samples }\end{array}$ & ND & $\begin{array}{l}\text { Cefuroxime and } \\
\text { fosfomycin X } \\
6 \text { weeks }\end{array}$ & [14] \\
\hline
\end{tabular}

Abbreviations: yo year-old, $M$ male, $N D$ not done, $P C N$ penicillin, $B L / B L$ Beta-lactam/Beta-lactamase, $R$ right, ref. No reference number.

and blood cultures [2]. We speculate that perineal and colonic flora contaminated and subsequently infected the above-described decubitus ulcer. The oxygen deficient environment of the decubitus wound coupled with extensive tissue necrosis created the perfect environment for this anaerobic bacterium to grow and thrive. Bedside surgical debridement allowed $P$. loescheii to invade the blood stream causing bacteremia and severe sepsis.

Prevotella spp. are non-motile, Gram-negative anaerobic bacilli. They are usually isolated from the mucosal surfaces of the mouth, colon and vagina in otherwise healthy individuals [5-8]. This anaerobe is considered an opportunistic pathogen [7]. To date, more than 50 species of Prevotella have been identified [9]. They have been implicated in the pathogenesis of periodontal infections with potential spread to adjacent structures [4,10-13]. Recently, however, there have been a number of cases in which Prevotella spp. caused infections at a distance from their primary source $[14,15]$.

Like all anaerobes, isolation of Prevotella spp. is difficult and requires appropriate methods for sample collection, transportation and culture. In vitro susceptibility testing of anaerobes is not performed routinely in many hospitals' clinical labs, including our hospital's microbiology lab. Hence, treatment of these infections is largely empiric and relies on reported susceptibilities from large medical centers and reference labs [16]. Of note, resistance among anaerobes has been rising; a number of studies have demonstrated increasing resistance among Prevotella spp. against $\beta$-lactam antibiotics and some have shown emergence of partial resistance to metronidazole as well [12,17-21].

Literature search revealed five reported cases of $P$. loescheii infection outside the oral cavity $[12,14,15]$. The salient features of cases reported in English language including the one at hand are summarized in Table 1 . There was a case of poly-microbial brain abscess in a child reported in Japanese and a case of mixed infection in a foot ulcer reported in French from Djibouti [22]. None of these 5 cases were associated with $P$. loescheii bacteremia at the time of diagnosis. Upon reviewing the above cases the following was noticeable:

1. Patients' ages varied widely but they were all males.

2. Large intestine was the source of infection in our patient, while the oral-nasal cavity was the source of bacteria in other cases.

3. The nosocomial case presented here was in contrast to the others, which were all community-acquired.

4. The presented case was polymicrobial, while the others were mono-microbial.

5. None of the reported cases died but they all required a lengthy course of antibiotic therapy.

\section{Conclusion}

Our case, underscores the potential increase in virulence among opportunistic pathogens like $P$. loescheii, especially in the ever-growing population of medically compromised patients. With changing antimicrobial resistance described over the last three decades, further work is needed to identify these anaerobes' mechanism of transmission, spectrum of disease and best antimicrobial therapy.

\section{Consent}

Written informed consent was obtained from the patient for publication of this case report and any accompanying images. A copy of the written consent is available for review by the Editor of this journal.

\section{Competing interests}

The authors declared that they have no competing interests.

\section{Authors' contributions}

FAK and MN diagnosed and treated the patient. MM and NAJ reviewed the data and the literature and they wrote the manuscript's initial draft. FAK and MN edited the manuscript. All authors read and approved the manuscript. 


\section{Author details}

${ }^{1}$ Section of Infectious Diseases, Department of internal medicine, Texas Tech University Health Sciences Center, 1400 S. Coulter Street, Amarillo, TX 79106, USA. 2Department of Surgery, Texas Tech University Health Sciences Center, Amarillo, Texas, USA

Received: 1 October 2013 Accepted: 21 March 2014

Published: 24 March 2014

\section{References}

1. Brem H, Nierman DM, Nelson JE: Pressure ulcers in the chronically critically ill patient. Crit Care Clin 2002, 18(3):683-694.

2. Bowler PG, Duerden Bl, Armstrong DG: Wound microbiology and associated approaches to wound management. Clin Microbiol Rev 2001, 14(2):244-269.

3. Brook I: Microbiological studies of decubitus ulcers in children. J Pediatr Surg 1991, 26(2):207-209.

4. Yanagisawa M, Kuriyama T, Williams DW, Nakagawa K, Karasawa T: Proteinase activity of prevotella species associated with oral purulent infection. Curr Microbiol 2006, 52(5):375-378.

5. Kononen E: Pigmented Prevotella species in the periodontally healthy oral cavity. FEMS Immunol Med Microbiol 1993, 6(2-3):201-205.

6. Tsang CS, Samaranayake LP: Predominant cultivable subgingival microbiota of healthy and HIV-infected ethnic Chinese. APMIS 2001 109(2):117-126.

7. Kononen E, Asikainen S, Saarela M, Karjalainen J, Jousimies-Somer H: The oral gram-negative anaerobic microflora in young children: longitudinal changes from edentulous to dentate mouth. Oral Microbiol Immunol 1994, 9(3):136-141.

8. Kononen $\mathrm{E}$, Jousimies-Somer $\mathrm{H}$, Asikainen $\mathrm{S}$ : The most frequently isolated gram-negative anaerobes in saliva and subgingival samples taken from young women. Oral Microbiol Immunol 1994, 9(2):126-128.

9. Parte AC: LPSN-list of prokaryotic names with standing in nomenclature. Nucleic Acids Res 2014, 42(1):D613-D616.

10. Hoshino T, Nakamura A: Clinical and bacteriological features of six cases with intracranial abscess in childhood. Kansenshogaku Zasshi 2002, 76(2):83-88

11. Bancescu G, Dumitriu S, Băncescu A, Preoteasa E, Skaug N: Prevotella species involved in the onset of superficial face and neck abscesses. Bacteriol Virusol Parazitol Epidemiol 2004, 49(3-4):131-136.

12. Sandoe JA, Struthers JK, Brazier JS: Subdural empyema caused by Prevotella loescheii with reduced susceptibility to metronidazole. J Antimicrob Chemother 2001, 47(3):366-367.

13. van Winkelhoff AJ, Winkel EG, Barendregt D, Dellemijn-Kippuw N, Stijne A, van der Velden U: Beta-Lactamase producing bacteria in adult periodontitis. J Clin Periodontol 1997, 24(8):538-543.

14. Steingruber I, Bach CM, Czermak B, Nogler M, Wimmer C: Infection of a total hip arthroplasty with Prevotella loeschii. Clin Orthop Relat Res 2004, 418:222-224.

15. Fe Marques A, Maestre Vera JR, Mateo Maestre M, González Romo F, Castrillo Amores MA: Septic arthritis of the knee due to Prevotella loescheii following tooth extraction. Med Oral Patol Oral Cir Bucal 2008, 13(8):E505-E507

16. Aldridge KE, Ashcraft D, Cambre K, Pierson CL, Jenkins SG, Rosenblatt JE: Multicenter survey of the changing in vitro antimicrobial susceptibilities of clinical isolates of Bacteroides fragilis group, Prevotella, Fusobacterium, Porphyromonas, and Peptostreptococcus species. Antimicrob Agents Chemother 2001, 45(4):1238-1243.

17. Kononen E, Nyfors S, Mättö J, Asikainen S, Jousimies-Somer H: Beta-lactamase production by oral pigmented Prevotella species isolated from young children. Clin Infect Dis 1997, 25(2):S272-S274

18. Sherrard LJ, Graham KA, McGrath SJ, Mcllreavey L, Hatch J, Muhlebach MS, Wolfgang MC, Gilpin DF, Elborn JS, Schneiders T, Tunney MM: Antibiotic resistance in Prevotella species isolated from patients with cystic fibrosis. J Antimicrob Chemother 2013, 68(10):2369-2374.

19. Maestre JR, Bascones A, Sánchez $P$, Matesanz $P$, Aguilar L, Giménez MJ, Pérez-Balcabao I, Granizo JJ, Prieto J: Odontogenic bacteria in periodontal disease and resistance patterns to common antibiotics used as treatment and prophylaxis in odontology in Spain. Rev Esp Quimioter 2007, 20(1):61-67.
20. Bahar H, Torun MM, Demirci M, Kocazeybek B: Antimicrobial resistance and beta-lactamase production of clinical isolates of prevotella and porphyromonas species. Chemotherapy 2005, 51(1):9-14

21. Wybo I, Van den Bossche D, Soetens O, Vekens E, Vandoorslaer K, Claeys G, Glupczynski Y, leven M, Melin P, Nonhoff C, Rodriguez-Villalobos H, Verhaegen J, Piérard D: Fourth Belgian multicentre survey of antibiotic susceptibility of anaerobic bacteria. J Antimicrob Chemother 2014, 69(1):155-61.

22. Kerleguer A, Koeck JL, Girard-Pipau F, Nicand E: Outbreak of tropical phagedenic ulcers after the rainy season in Dijibouti. Med Trop (Mars) 2003, 63(2):194-196.

doi:10.1186/1471-2334-14-162

Cite this article as: Mehmood et al: Bacteremic skin and soft tissue infection caused by Prevotella loescheii. BMC Infectious Diseases 2014 14:162.

\section{Submit your next manuscript to BioMed Central and take full advantage of:}

- Convenient online submission

- Thorough peer review

- No space constraints or color figure charges

- Immediate publication on acceptance

- Inclusion in PubMed, CAS, Scopus and Google Scholar

- Research which is freely available for redistribution 